\title{
Pulpotomy in deciduous tooth with mineral trioxid aggregate
}

\author{
Pulpotomia em molar decíduo com agregado trióxido mineral
}

Fabiane PIVA ${ }^{1}$

Fábio Herrmann COELHO-DE-SOUZA²

Raquel MEIRA ${ }^{3}$

Gabriela Taube ROTTA'

Taytianne VOLKWEISS 1

\begin{abstract}
Several medicines have been tested and used in the conservative pulp therapy of deciduous teeth, however, the formocresol has being the elected material in the pulpotomies, even not assisting the biocompatibility demands and promoting the fixation of the vital pulp tissue and not its repair. After Mineral Trioxide Aggregate (MTA) appearance as a material with physico-chemical properties that promotes the tissue repair, allied to other important properties, such as the antimicrobial action and the biocompatibility to the pulpal tissues, a new alternative material appeared for the dentistry. The aim of this study was to report the effect of MTA in a pulpotomy of deciduous molar, and its 1-year follow-up. The pulpotomy was made with MTA in the tooth 85 in a 5-year-old patient. The results obtained were quite favorable, demonstrating clinical and radiographic success, as well as absence of painful symptomatology reported by the patient. In spite of the little time of follow-up of the treated deciduous tooth, MTA has a great biological potential and could be an alternative material to be used in the pulpotomies of deciduous teeth.
\end{abstract}

Indexing terms: Dental cements. Pulpotomy. Tooth deciduous.

\section{RESUMO}

Diversos medicamentos vêm sendo testados e utilizados na terapia pulpar conservadora de dentes decíduos, no entanto, o formocresol continua sendo o material de escolha nas pulpotomias, mesmo não atendendo às exigências de biocompatibilidade e promovendo a fixacão do tecido pulpar vital e não o seu reparo. Com o surgimento do Agregado Trióxido Mineral (MTA) como um material com propriedades físico-químicas que promovem o reparo tecidual, aliados a outras propriedades importantes, tais como a ação antimicrobiana e a biocompatibilidade aos tecidos pulpares surgiu uma nova alternativa de material na Odontologia. O objetivo deste estudo foi relatar o desempenho do MTA em uma pulpotomia em molar decíduo e seu acompanhamento por um período de 1 ano. Foi realizada a pulpotomia com o uso do MTA no dente 85 de um paciente de 5 anos de idade cujos resultados obtidos foram bastante favoráveis, demonstrando sucesso clínico e radiográfico no período avaliado. Apesar do pouco tempo de acompanhamento do dente decíduo tratado, acredita-se que o MTA possa ter um grande potencial biológico e futuramente podendo transformar-se em uma opção de material para ser utilizado como rotina nas pulpotomias de dentes decíduos.

Termos de indexação: Cimentos dentários. Pulpotomia. Dente decíduo.

\section{INTRODUCTION}

Deciduous teeth have a great importance to children regarding aesthetics, occlusion and phonetics, besides keeping the space for the permanent teeth. In deciduous teeth, caries is still one of the most frequent oral disease in the childhood ${ }^{1-2}$. Because of the high incidence and severity in children, caries lesions may promote pulpal exposures that would need pulp therapy.

Regarding the different treatments for deciduous pulp, the pulpotomy is a current option. The procedure has a conservative approach with good clinical results, and preserves the tooth until the exfoliation ${ }^{3-4}$. Pulpotomy is usually performed in deciduous teeth with large pulp exposures after caries removal, and requires total removal of the coronal pulp and preservation of the radicular portion through materials that keep its integrity or simply promote its fixation.

Formocresol is still one of the most frequent material used in pulpotomy in deciduous teeth ${ }^{5}$. Although formocresol have showed good clinical outcomes, there is no consensus in the literature about the use of this medication. Pulpal reactions, periapical effects and damages in the dental follicle of the successor tooth are adverse effects related to the formocresol, besides toxic and mutagenic potential6-7. Thus, other materials have also been used in pulpotomy in deciduous teeth, such as: calcium hydroxid, glutaraldehyde, ferric sulfate, lyophilized bone, osteogenic protein and eventually mineral trioxide aggregate (MTA) $)^{3,8-9}$.

\footnotetext{
${ }^{1}$ Universidade Luterana do Brasil, Curso de Odontologia. Rua Martinho Lutero, 301, Bairro Universitário, 96501-595, Cachoeira do Sul, RS, Brasil. Correspondência para / Correspondence to: F PIVA. E-mail:<fabi.piva@ig.com.br>.

${ }^{2}$ Universidade Federal do Rio Grande do Sul, Curso de Odontologia, Departamento de Odontologia Conservadora. Porto Alegre, RS, Brasil.

${ }^{3}$ Consultório particular. Porto Alegre, RS, Brasil.
} 
MTA showed up in the 90's, with studies about its biological and physical properties ${ }^{4,10-12}$. The composition of MTA is based on mineral oxides, calcium and phosphate, that promotes biocompatibility. The initial $\mathrm{pH}$ of the MTA in a moisture environment is 10.2, reaching 12.5 after 3 hours. This characteristic promotes alkalinization of the site and antimicrobial effect. When MTA is added straight on the pulpal tissue, there is a mineral deposition, creating a mineral barrier (dentin bridge), with a low level of inflammatory response, 13-17. Further, other characteristics attributed to MTA are: mechanical strength, adequate setting time, good marginal sealing and low shrinkage ${ }^{10-11,13}$. On the other hand, Coelho et al. ${ }^{4}$ highlighted some disadvantages for this material, such as: high costs, handling difficulties and low initial resistance to displacement.

Pulpotomies in deciduous teeth with MTA were already done with clinical and radiographic success; however, there is a lack of information about the longterm evaluation $3-4,18$. Therefore, the aim of this study was to report the effect of MTA in a pulpotomy of a deciduous molar, and its 1-year follow-up.

\section{CASE REPORT}

For the case report, a patient from the pediatric dentistry clinic (Lutheran University of Brazil, Cachoeira do Sul, RS, Brazil) was selected. All infant patients in this University have consent and authorization from their parents to allow clinical procedures.

The selected patient was male, age of 5 years and 8 months, and had caries activity with a large lesion in the tooth 85. In the first appointment, a clinical and radiographic examination was done. In the radiograph, there was no radiolucent image in the periapex and interroot, and the roots had acceptable length (Figure 1). In the clinical examination, the tooth did not show any fistula or spontaneous painful symptoms (Figure 2).

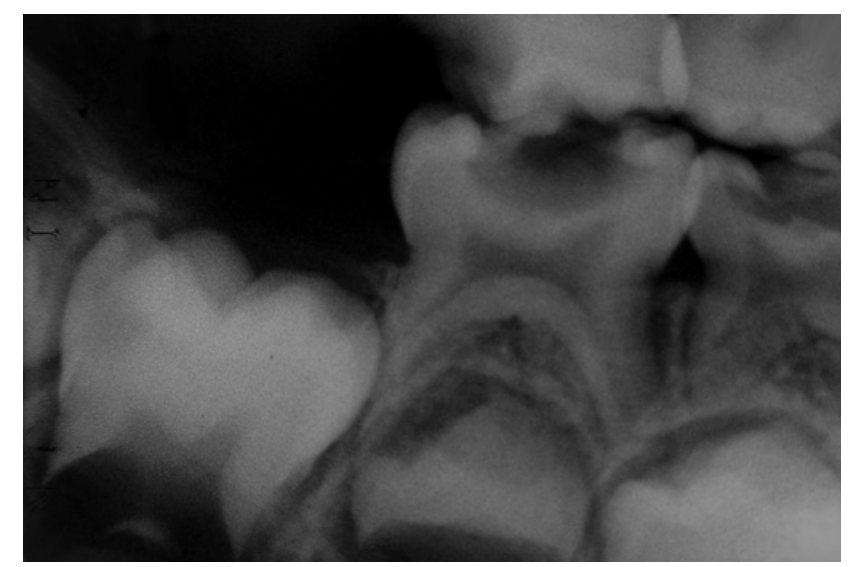

Figure 1. Initial radiographic examination (tooth 85).

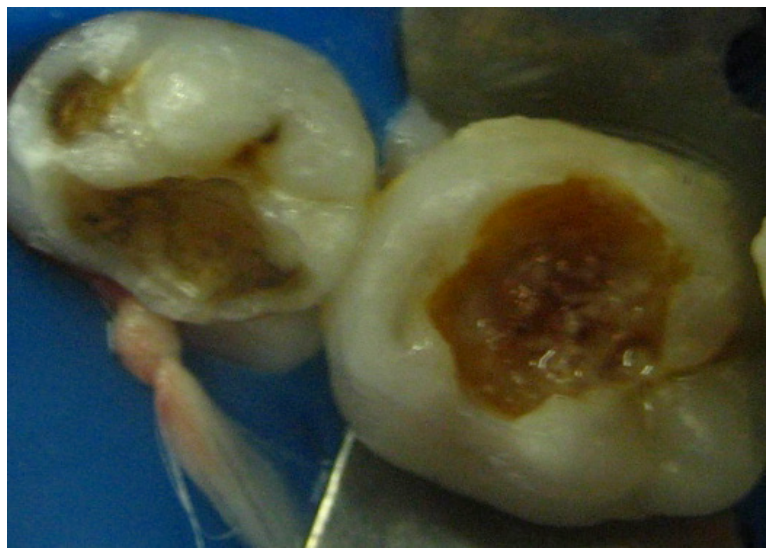

Figure 2. Clinical aspect of tooth 85 .

The clinical procedure starts with the anesthesia, topical first (Lidopass, São Paulo, Brazil, lot 602) for 2 minutes, and then infiltrative with mepivacaine 2\% (Mepilevo, DFL, Rio de Janeiro, Brazil, Lot: 0606 G 03). After the placement of rubber dam, all caries tissue was removed with steel round burs. When the unavoidable pulp exposure happened, the pulp chamber was accessed with Endo-Z bur, and we could do a visual examination of the quality of the coronal pulp (color, consistence and bleeding aspect). All characteristics evaluated were suitable to the pulpotomy procedure. The coronal pulp tissue was removed through dentin excavator using (Duflex, Joinvile, Brazil). Once hemostasis was achieved, MTA was applied on the remaining pulp tissue (MTA white, Angelus, Lot: 1589, Londrina, Brazil). The MTA material was manipulated according the manufacturer's instructions. After the MTA adding (Figure 3), the tooth cavity was filled with glass ionomer cement (Ketac Fill Plus, 3M ESPE, Sumaré, Brazil, Lot: 255496).

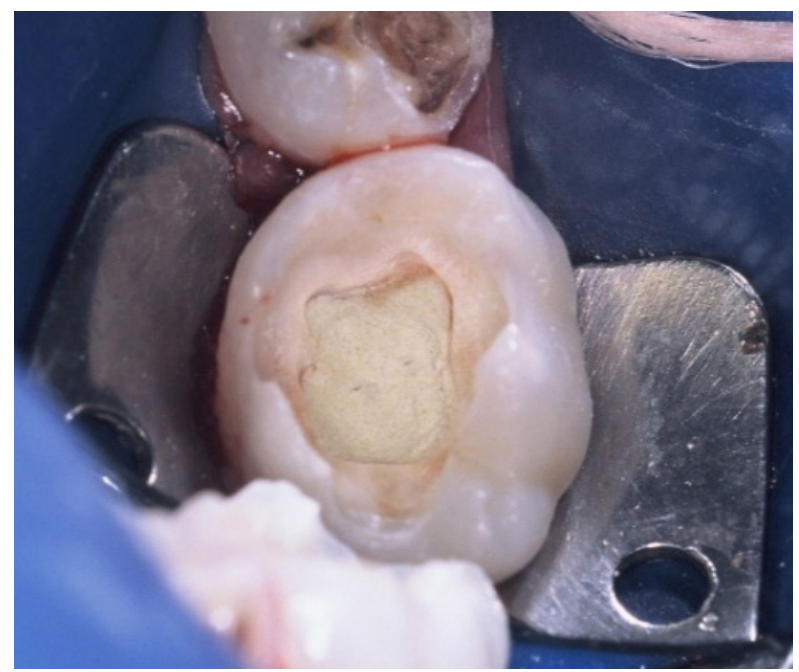

Figure 3. MTA applied on the remaining pulp tissue. 

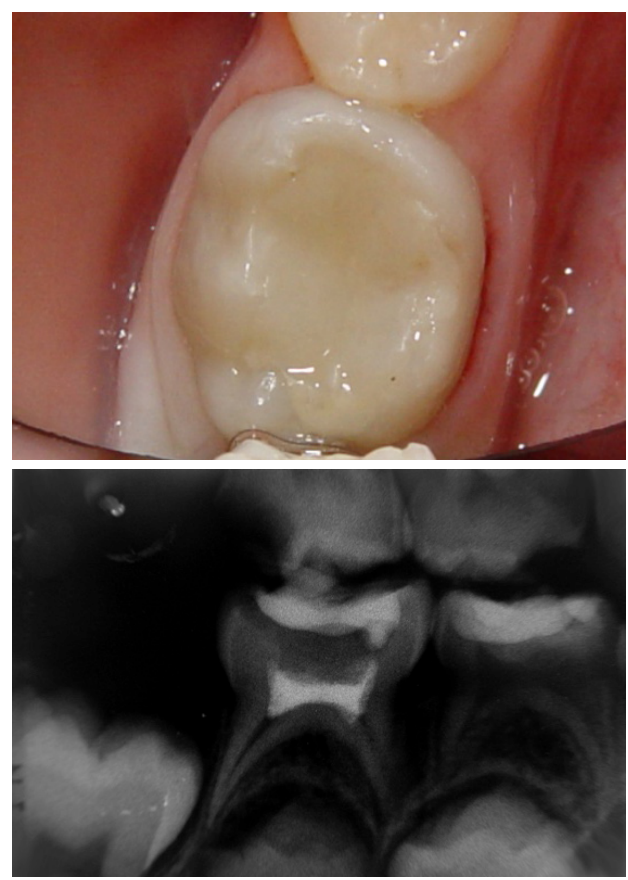

Figure 4. Clinical and radiographic aspect of tooth 85 after 30 days.
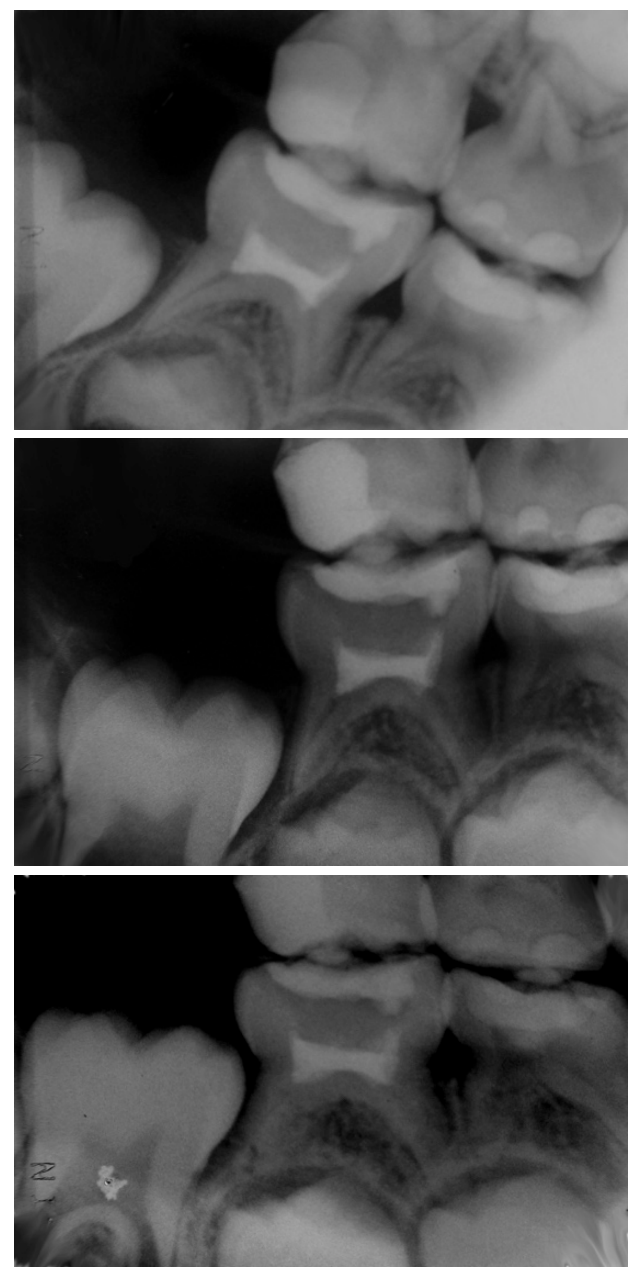

Figure 5. Radiographic examination in 90, 180 days and 1 year follow-up (tooth 85).
One week later, the child came back in another appointment for clinical and radiographic evaluation. There was no painful symptoms related by the patient and his parents, and all criteria evaluated were adequated. Thus, the tooth was restored with composite resin. Under rubber dam, the glass ionomer cement was partially removed (liner) and the dentin-bonding agent was applied (Scothbond multipurpose, 3M ESPE), followed by Charisma composite (Heraeus Kulzer, Germany, Lot: 010204), in A1 shade, by incremental technique. Finishing and polishing were performed immediately with Enhance points (Dentsply, PA, USA).

The patient remained in the clinic until the whole treatment planning was completed. One month after the pulpotomy procedure, the clinical and radiographic aspects were normal, with no fistula or symptoms (Figure 4). The 90 days, 180 days and 1 year follow-up also showed the same favorable conditions (Figure 5).

\section{DISCUSSION}

This current case report showed the use of MTA in pulpotomy of deciduous tooth, according to some published studies ${ }^{3-4,18}$. MTA has some interesting characteristics, like: biocompatibility, antimicrobial effect, mechanical strength, adequate setting time, good marginal sealing, low shrinkage and can be applied even in moisture area ${ }^{10-11,13,14,15,17}$. Even though the formocresol is still one of the most frequent material used in pulpotomy in deciduous teeth ${ }^{5}$, it has some disadvantages for the vital tissue, such as: pulpal reactions, periapical effects and damages in the dental follicle of the successor tooth, besides toxic and mutagenic potencial6-7,19-22.

The antimicrobial effect of the MTA has been seen against a bunch of microorganisms ${ }^{13,19}$. The initial $\mathrm{pH}$ of the MTA is 10.2 , reaching 12.5 after 3 hours. This characteristic promotes alkalinization of the site and the antimicrobial effect. When MTA is added straight on the pulpal tissue, there is a mineral deposition, creating a mineral barrier (dentin bridge), with a low level of inflammatory response 9,14-17.

Nonetheless, it is important to highlight some disadvantages of the MTA, especially about its costs. Thus, the professional could choose other materials which have similar clinical outcomes ${ }^{4}$.

The case reported in this current work had quite favorable results, demonstrating clinical and radiographic success, as well as absence of painful symptomatology reported by the patient, with agreement regarding the scientific literature ${ }^{3-4,18}$. However, the follow-up of this pulpotomy was just 1 year, so far. This short period of time is not enough to stablish the real behavior of MTA in 
pulpotomies of deciduous teeth. Randomized clinical trials are necessary to confirm our finds, and to allow the use of this material as routine in the pediatric dentistry.

\section{CONCLUSION}

The results of the pulpotomy with MTA were satisfactory in all periods of follow-up and painful symptomatology was not reported at any time by the patient or his parents. Further, no clinical and radiographic alterations or failure of the procedure were observed. Therefore, it is considered that the MTA has a promising future in the conservative pulp therapy of primary teeth.

\section{REFERENCES}

1. Wambier DS, Bosco VL, Cuman V, Smiguel O, Eloy TC. Prevalência e distribuição de lesões de cárie em bebês. Publ UEPG Ci Biol Saúde. 2004;10(1):15-22.

2. Silva JS, Silva FDSCM, Forte FDS, Sampaio FC. Prevalência de cárie e indicadores de risco em crianças de 2 a 6 anos na clínica de Odontologia preventiva. Rev Odonto Ciênc. 2006;21(51):17-21.

3. Chibinski ACR, Czlusniak GD. Utilização do agregado trióxido mineral (MTA) em pulpotomias de dentes decíduos: relato de caso. Publ UEPG Ci Biol Saúde. 2003;9(3/4):21-7.

4. Coelho A, Canta JP, Marques P. Pulpotomia de dentes decíduos com mineral trióxido agregado: caso clínico. Rev Port Estomatol Cir Maxilofac. 2005;46(2):101-6.

5. Kramer PF, Faraco Junior IM, Feldens CA. Estado atual da terapia pulpar nas universidades brasileiras - pulpotomia e pulpectomia em dentes decíduos. J Bras Odontopediatr Odontol Bebê. 2000;3(3):222-30

6. Sayão Maia SMA, Ribeiro PG, Marchiori EC. Estudo comparativo da ação do formocresol e glutaraldeído pós-pulpotomia: revisão de literatura. Rev Sul Bras Odontol. 2005;2:27-32.

7. Thomas MI, Gonçalves TS, Souza MAL, Schmitt VM. Formaldeído na odontologia: aspectos antimicrobianos,carcinogênicos e mutagênicos. um estudo da sua viabilidade na clínica odontológica. Rev Odonto Ciênc. 2006;21(54):387-91.

8. Massara MLA, Noronha JC, Souki BQ, Diniz APV, Navarro CF, Alencar MCBB, et al. A utilização do hidróxido de cálcio em pulpotomias de dentes decíduos. RGO - Rev Gaúcha Odontol. 1996;44(5):300-4.

9. Torabinejad $M$, Chivian N. Clinical applications of mineral trióxide aggregate. J Endod. 1999;25(3):197-205.

10. Torabinejad M, Hong CU, McDonald F, Pit Ford TR. Physical and chemical properties of a new root-end filling material. J Endod. 1995;21(7):349-53. doi: 10.1016/S0099-2399(06)80967-2

11. Torabinejad M, Hong CV, Pitt Ford TR, Kettering JD. Cytotoxity of four root end filling material. J Endod. 1995;21(10):489-92. doi: 10.1016/S0099-2399(06)80518-2
However, the success of pulp therapy also depends on an accurate diagnosis, the patient's age, the pulp characteristics and the biological response capacity of the patient.

\section{Collaborators}

F PIVA attended the orientation of clinical procedures and the writing of the article. FH COELHO-DESOUZA participated as advisor of the restorative technique and reviews the article. R MEIRA participated in the images capture and literature review. GT ROTTA and T VOLKWEISS were responsible for the conduct of the case reported and participated in the writing of the article.

12. Duda JG, Losso EM. O uso do agregado trióxido mineral (MTA) em odontopediatria. Arg Odontol. 2005;41(1):93-103.

13. Torabinejad M, Hong CU, Pit Ford TR, Kettering JD. Antibacterial effects of some root end filling materials. J Endod. 1995;21(8):403-6.

14. Faraco IM Jr, Holland R. Response of the pulp of dog to capping with mineral trioxide aggregate or a calcium hydroxide cement. Dental Traumatol. 2001;17(4):163-6. doi: 10.1034/j.16009657.2001.170405.x

15. Faraco IM Jr, Holland R. Histomorphological response of dogs' dental pulp capped with white mineral trioxide aggregate. Braz Dent J. 2004;15(2):104-8. doi: 10.1590/S0103-64402004000200004

16. Schmitt D, Lee J, Bogem G. Multifaceted use of ProRoot MTA root canal repair material. Pediatr Dent. 2001;23(4):326-30.

17. Menezes R, Bramante CM, Garcia RB, Letra A, Carvalho VGG, Carneiro $E$, et al. Microscopic analysis of dog dental pulp after pulpotomy and pulp protection with mineral trioxide aggregate and White portland cement. J Appl Oral Sci. 2004;2(2):104-7. doi: 10.1590/S1678-77572004000200004

18. Maroto-Edo M, Barbería-Leache E, Planells del Pozo P. Estudio clínico del agregado trióxido mineral en pulpotomias de molares temporales: estudio piloto a 15 meses. RCOE - Rev llustre Cons Gen Col Odontol Estomal Esp. 2004;9(1):23-30. doi: 10.4321/ S1138-123X2004000100002

19. Stowe TJ, Sedgley CM, Stowe B, Fenno JC. The effects of chlorhexidine gluconate $(0.12 \%)$ on the antimicrobial properties of tooth-colored ProRoot mineral trioxide aggregate. J Endod. 2004;30(6):429-31. doi: 10.1097/00004770-200406000-00013

21. Kettering JD, Torabinejad M. Investigation of mutagenicity of mineral trioxide aggregate and other commonly used root-end filling materials. J Endod. 1995;21(11):537-9. doi: 10.1016/ S0099-2399(06)80980-5

22. Fernandes DSC, Faraco IM Jr, Kramer PF, Ulian J. Pulpotomias com formocresol em dentes decíduos. RGO - Rev Gaúcha Odontol. 2003;51(3):154-61. 